\title{
Government takes on fraud
}

\section{Scandal-weary administration sets up agency to investigate serious research misconduct.}

\section{BY HOLLY ELSE}

$\mathrm{B}$ ruised by a string of high-profile scientific-misconduct cases, Sweden has laid the legislative groundwork for a government agency that will handle all allegations of serious research misconduct. The country follows in the footsteps of neighbouring Denmark, which created the world's first such agency in 2017.

Proponents say that handling researchmisconduct investigations centrally should ensure equal, impartial treatment. But others say the move will divert resources and attention away from less serious breaches that universities will continue to deal with in-house and which, they argue, cumulatively do more damage than some more serious misdemeanours.

The way in which Swedish research institutes handle allegations of misconduct has come under fire in recent years - thanks in part to the case of trachea surgeon Paolo Macchiarini.
Macchiarini had been accused of misconduct relating to trials of an experimental tracheatransplant method, in which some patients died. The Karolinska Institute in Stockholm initially cleared him, but later investigations found that he had committed misconduct. A 2016 independent commission concluded that the institute's procedures were flawed.

The Swedish government launched an independent inquiry in 2015 to investigate whether new sys-

tems were needed for "It became dealing with research very messy." misconduct. But the

Macchiarini case "changed the whole landscape" of how to approach research misconduct in Sweden, says Margaretha Fahlgren, who studies literature at Uppsala University and led the inquiry. "It became very messy," she adds.

In 2017 , the inquiry recommended to Sweden's research ministry that research organizations refer all cases of alleged misconduct to a new government agency - to be called the Research Misconduct Board - for investigation. The board, it advised, should be chaired by a judge and consist of up to ten scientists with expertise in different fields.

The agency will be created through a law that passed parliament in June and is expected to come into force in January 2020. The law defines research misconduct as fabrication, falsification or plagiarism. All cases of alleged serious research misconduct at publicly funded research institutes will be referred to the board for investigation. Findings will be made public and be legally binding for universities, which will decide the consequences for researchers.

The system is an improvement, says Karin Åmossa, head of research and international affairs at the Swedish Association of University Teachers and Researchers in Stockholm. Currently, institutions investigate most allegations internally, which can lead to some cases not being treated fairly or transparently, she says. .

\section{nature research EDITING SERVICE}

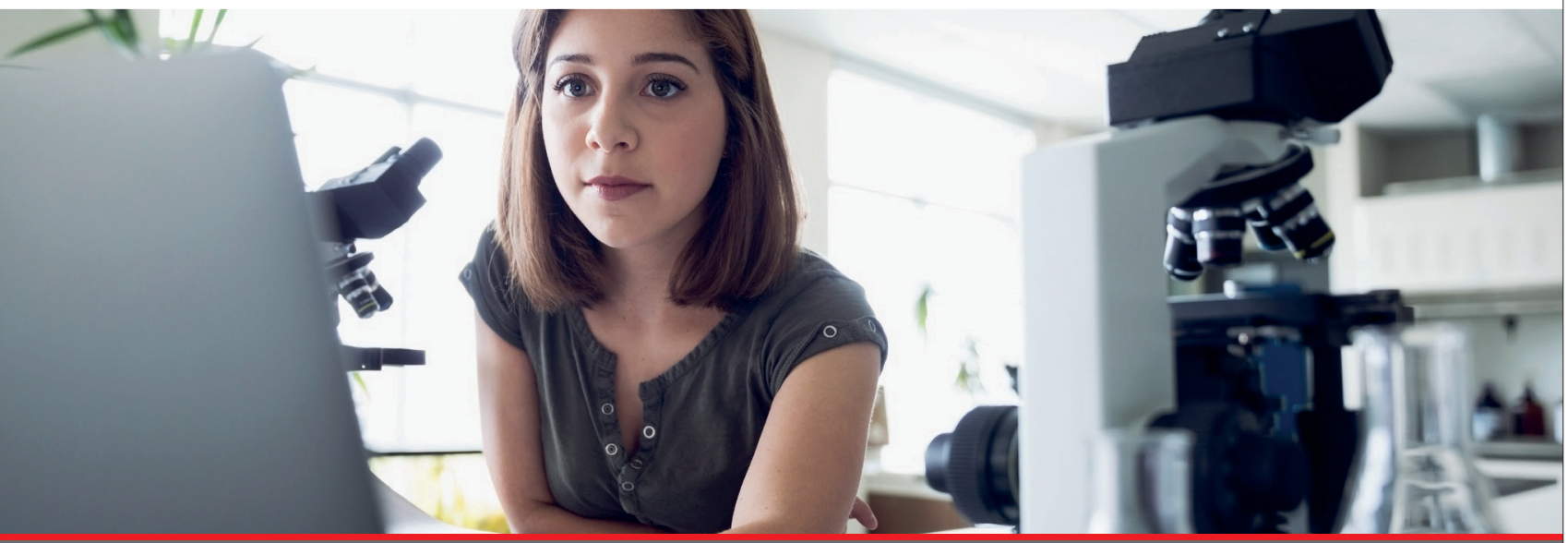

Could you communicate your research more effectively?

Our editors understand what it takes to get published and can offer expert advice to help

you optimise your research paper or grant proposal.

Learn more at authorservices.springernature.com/scientific-editing 